\title{
1. PALEOMAGNETISM AND MAGNETIC PROPERTIES OF IGNEOUS ROCK SAMPLES-LEG 38
}

\author{
Dennis V. Kent and Neil D. Opdyke, Lamont-Doherty Geological Observatory \\ of Columbia University, Palisades, New York
}

\section{INTRODUCTION}

Basaltic rock was recovered from nine sites on Leg 38 . Initially, one to three partially oriented specimens in the form of right-circular cylinders, $2.5 \mathrm{~cm}$ in diameter and $2.5 \mathrm{~cm}$ high, were obtained from each of these sites for preliminary magnetic studies. The studies included measurement of intensity and direction of remanent magnetism, susceptibility, stability of remanence against alternating fields, and thermomagnetic characteristics. Additional samples were taken subsequently from cores some of the sites in order to resolve some discrepancies apparent in our initial observations, particularly at Site 336, as well as between these and measurements on the same rocks made by Russian workers. Results from the additional samples are incorporated in this report.

\section{MAGNETIC PROPERTIES}

\section{Natural Remanent Magnetization and Susceptibility}

The direction and intensity of natural remanent magnetization (NRM) were measured in each specimen with a spinner magnetometer; the specimen's initial susceptibilities were measured with an AC bridge (Figure 1). The site mean values of NRM intensity (Table 1) were within the range $1 \times 10^{-3}$ to $2 \times 10^{-2} \mathrm{G}$, and similar to the range of NRM intensities found in other DSDP basalts (Lowrie, 1974), except at Site 344 which gave an unusual low site mean. The site mean susceptibilities were also within the range of other DSDP basalts $\left(10^{-4}\right.$ to $\left.10^{-2} \mathrm{G} / \mathrm{oe}\right)$, but at seven of the nine sites, the mean susceptibility was a factor of two or more greater than the mean $\left(0.63 \times 10^{-4} \mathrm{G} /\right.$ oe $)$ for other DSDP basalts (Lowrie, 1974).

The modified Königsberger, $Q n^{\prime}(=N R M / k)$ varies from 0.1 to 45 , with most values falling between 1 and 10 (Figure 1). The site mean values of the Königsberger ratio, calculated with the 1965.0 International Geomagnetic Reference Field at each site, were greater than 1, except at Site 344 which had a low value of 0.46 (Table 1). Due to the high susceptibilities, the site mean Königsberger ratios generally were less than the average Königsberger ratio (7.92) reported for other DSDP basalts (Lowrie, 1974). Although the remanence was the dominant magnetization component in most cases, induced magnetization components cannot be considered insignificant at several sites, particularly at Site 344 in which the induced component dominated the magnetization.

\section{Stability and Direction of Magnetization}

Alternating field (AF) demagnetization in progressively higher fields to 500 -oe peak was used to in- vestigate the stability of the NRM of each specimen. Vector diagrams illustrating the effects of this treatment on two representative specimens are shown in Figure 2. The direction of stable remanence, the demagnetizing field at which it was obtained, and the direction of NRM for comparison are shown for each specimen in Table 2. The median destructive field (MDF) and the fraction of the NRM remaining after AF treatment in 100 oe were determined for each specimen and are also shown in Table 2.

Stable magnetic properties were found at Sites 336 and 337. The basalts at these sites possessed high MDF and experienced little change in magnetic directions with AF treatment (Figure 2). Appreciable soft components of magnetization often were present in the basalts from the other sites, reflected either by low MDF (e.g., Sites 338, 343, and 345), or large directional changes in remanence after AF demagnetization (Site 344; Figure 2). The least stable magnetizations were present at Sites 348 and 350. The NRM at these sites had low MDF, and the magnetic inclination directions often changed from positive (directed down) to steeply inclined upward after partial AF demagnetization. Nevertheless, it was possible to isolate a stable magnetization at these and the other sites after the removal of soft magnetic components by AF demagnetization.

The magnetic inclinations of DSDP samples are meaningful because the vertical direction usually is known, provided that care is taken in preserving the original orientation of the sample. In addition, the high paleolatitudes of these sites result in steep inclinations from whose sense the magnetic polarity can be determined readily. The polarity of the geomagnetic field was most likely normal at the time of basement formation at Sites 338, 343, and 345, and reversed during the formation of Sites 336, 342, 344, 348, and 350: both normally and reversely magnetized samples occurred at Site 337 (Table 2). The remanence of some specimens from three reversely magnetized sites $(342,344$, and 350 ) showed an initial increase in magnetization after AF treatment $(J 100 / \mathrm{NRM}>100 \%$; Table 2$)$. This behavior can be attributed to the removal of a soft component directed along the present in situ magnetic field, antiparallel to the stable reversed remanence, and supports the interpretation of reversed magnetization in at least three of the five reversed sites.

The cleaned remanent inclinations, regardless of sign, were, on the average, steeply dipping at most sites (Table 3 ) as would be expected from the high paleolatitudes of Greenland and western Europe since the lower Tertiary. Two exceptions were Sites 336 and 337 , which had mean inclinations substantially shallower than at the other Leg 38 sites. Moreover, 


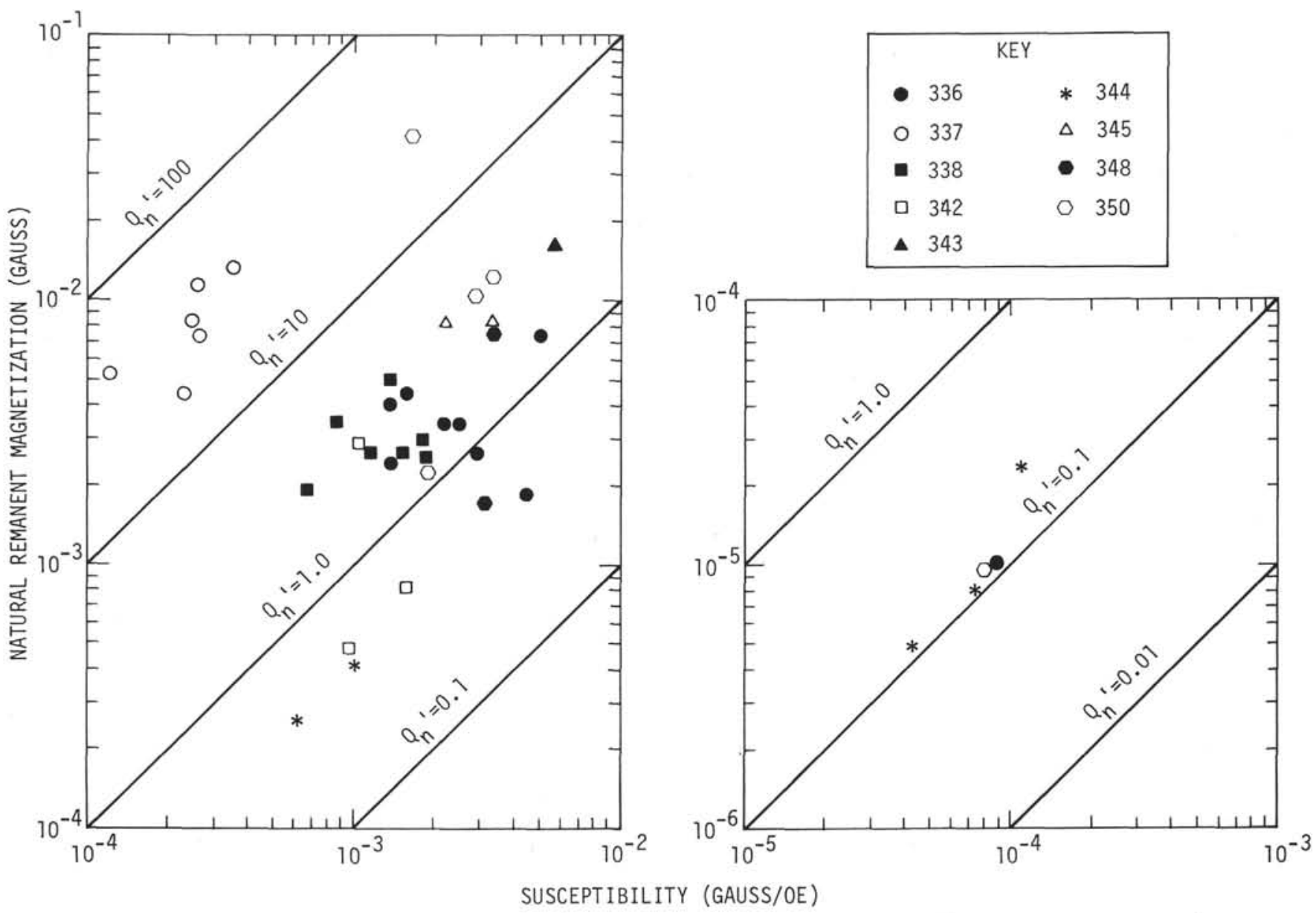

Figure 1. Intensity of natural remanent magnetization (NRM) and the susceptibility $(\mathrm{k})$ of Leg 38 basalts. $\mathrm{Q}_{\mathrm{n}}{ }^{\prime}$ is the ratio $N R M / k$

TABLE 1

Site Mean Values of Natural Remanent Magnetization (NRM), Susceptibility $(k)$, and Königsberger Ratio

\begin{tabular}{ccccc}
\hline & $\begin{array}{c}\text { Number } \\
\text { of } \\
\text { Samples }\end{array}$ & $\begin{array}{c}\text { NRM } \\
\left(10^{-4} \mathrm{G}\right)\end{array}$ & $\begin{array}{c}k \\
\left(10^{-4} \mathrm{G} / \mathrm{oe}\right)\end{array}$ & $\begin{array}{c}\text { Königsberger } \\
\text { Ratio }\end{array}$ \\
\hline 336 & 9 & 33.6 & 23.9 & 2.92 \\
337 & 6 & 84.9 & 2.41 & 69.5 \\
338 & 7 & 30.9 & 13.1 & 5.01 \\
342 & 3 & 14.4 & 12.0 & 2.33 \\
343 & 1 & 164.4 & 57.1 & 5.59 \\
344 & 5 & 1.45 & 3.86 & 0.46 \\
345 & 2 & 82.7 & 27.2 & 5.85 \\
348 & 2 & 47.0 & 33.2 & 2.75 \\
350 & 5 & 46.2 & 19.9 & 13.0 \\
\hline
\end{tabular}

both normally and reversely magnetized samples occurred at Site 337, although the reversed samples generally had steeper inclinations than the normally magnetized samples. It is possible that the polarity of the geomagnetic field was reversed during the formation of this site, reflected by the steep negative inclinations. The more shallow inclinations, both positive and negative, are probably due to sampling of basalt breccia that has been identified at this site, in which fragments of basalt may have been physically rotated after they had acquired a magnetization.

\section{Magnetic Mineralogy}

Curie point analysis was carried out on representative specimens from each site to determine the dominant magnetic mineralogy. Small chips of basalt were ground to a coarse powder and heated in air in a vertical motion type, automatically recording Curie balance. It was not possible to obtain thermomagnetic curves for samples from Site 344; the concentration of magnetic minerals at this site was evidently insufficient to produce a usable signal under the experimental conditions used. The Curie temperatures observed in the thermomagnetic heating curves of the other samples are listed in Table 4.

Samples from a majority of the sites $(337,343,345$, 348 , and 350) gave irreversible thermomagnetic curves (Figure 3a) typical of those found in most rapidly quenched, submarine basalts (Ozima and Ozima, 1971; Lowrie, 1974). The Curie points observed during heating ranged from $190^{\circ} \mathrm{C}$ to $405^{\circ} \mathrm{C}$, and during cooling they ranged from $505^{\circ} \mathrm{C}$ to $530^{\circ} \mathrm{C}$, corresponding to a low-titanium magnetite. The Curie point observed during heating can be attributed to the presence of 


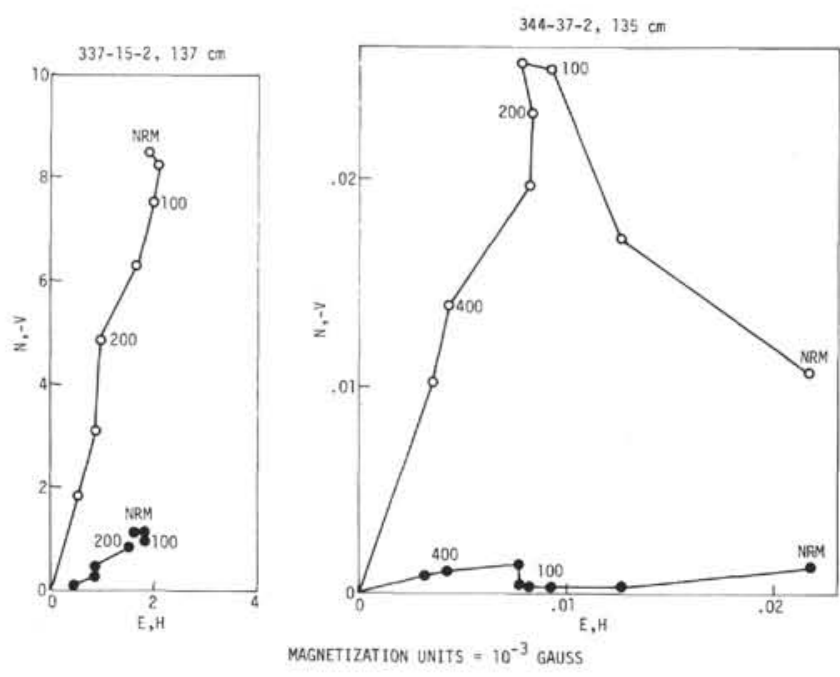

Figure 2. Vector diagram showing the AF demagnetization stability of the NRM of two basalt specimens from Leg 38. The northward $(N)$ and eastward $(E)$ components define the declination variation (solid circles) relative to an arbitrary zero; the horizontal $(H)$ and vertical $(V)$ components define the inclination variation (open circles). Numbers next to selected points refer to the peak demagnetizing field intensity in oersteds.

either titanomagnetite, or the cation-deficient form, titanomaghemite as the dominant magnetic mineral.

Samples from Site 336 each gave a nearly reversible thermomagnetic curve (Figure 3b). A single high temperature Curie point (range from $545^{\circ} \mathrm{C}$ to $565^{\circ} \mathrm{C}$ ) was observed during both heating and cooling and can be attributed to a magnetic mineral close in composition to magnetite.

The thermomagnetic behavior of samples from Sites 338 and 342 was more complex, and as for Site 336 samples, uncharacteristic of normal oceanic basalt. Two Curie points were observed during heating: between $230^{\circ} \mathrm{C}$ and $315^{\circ} \mathrm{C}$ and between $485^{\circ} \mathrm{C}$ and $565^{\circ} \mathrm{C}$. Only a single Curie point, in the range from $510^{\circ} \mathrm{C}$ to $535^{\circ} \mathrm{C}$, was observed during cooling (Figure $3 \mathrm{c})$. The double Curie points indicate the presence of two magnetic mineral phases, most probably titanomagnetite (or titanomaghemite) and a low titanium magnetite.

\section{DISCUSSION}

If we make the gross assumption that the limited number of basalt samples studied here are representative of the magnetized layer at each site, it is apparent that at many of the sites necessary, but insufficient, magnetic properties occur for straightforward interpretation of any marine magnetic anomalies according to the Vine and Matthews (1963) hypothesis. Although the Königsberger ratio was greater than 1 at most of the sites, the generally low values indicate that induced magnetization components may have a perturbing influence on the anomaly profiles over some areas. In the vicinity of Site 344, the low NRM intensities and Königsberger ratios of the sampled igneous rock suggest that variations in susceptibility, as opposed to alternations in the magnetization polarity, may be more important in producing any local magnetic anomalies.

The low median destructive field of basalts from Sites $343,345,348$, and 350 indicate the presence of a large soft component of magnetization. At two of the sites (348 and 350), the soft magnetization was of sufficient magnitude to mask the stable, reversed remanence of the basalt. DSDP basalts with these unstable remanent characteristics generally have been found in regions where linear magnetic anomaly patterns are absent or poorly developed (Lowrie, 1974) and are known to be very susceptible to acquisition of viscous remanence (Lowrie et al., 1973; Peirce et al., 1974). Remagnetization of the oceanic crust by viscous remanence acquisition has been offered as an explanation of some magnetic quiet zones (Lowrie, 1973). However, welldeveloped linear magnetic anomalies are reported to occur in the vicinity of at least two of the sites ( 343 and 348 ) which had unstable magnetic properties. This suggests that the recovered basaltic rocks may not be representative of the magnetized layer giving rise to the magnetic anomalies.

Curie point analysis revealed that the basalts at three sites (336, 338, and 342) had thermomagnetic characteristics not normally associated with submarine basalts. Curie temperatures of greater than $500^{\circ} \mathrm{C}$ were observed at these sites and may represent low-titanium titanomagnetite produced by the subsolidus exsolution of ilmenite from an originally homogeneous titanomagnetite, following high-temperature oxidation during initial cooling. Such features of deuteric, high temperature oxidation commonly have been observed in subaerial basalts (e.g., Ade-Hall et al., 1964). In contrast, most submarine basalts including those at the other Leg 38 sites have single, low Curie temperatures $\left(100^{\circ} \mathrm{C}\right.$ to $\left.400^{\circ} \mathrm{C}\right)$ attributed to the presence of a homogeneous titanomagnetite (or titanomaghemite).

At each of the sites with atypical thermomagnetic characteristics, evidence from overlying sediment suggests shallow water or even subaerial emplacement of the basalt. Site 336 was taken on the northern flank of the Iceland-Faeroe Ridge; the basaltic basement was covered by rubble probably derived from the basalt by subaerial erosion (Talwani et al., 1975). Basaltic rock underlying Sites 338 and 342 on the inner V $\phi$ ring Plateau may represent oceanic basement formed immediately after the opening of the Norwegian Sea (Talwani and Eldholm, 1972). The character of the overlying sediment at these two sites would imply that the basaltic basement was initially at or above sea level. In addition, the basalts recovered at all three of these sites are more similar petrologically to plateau basalt than to typical oceanic tholeiites.

Atypical thermomagnetic characteristics, similar to those observed at Sites 336, 338, and 342, were measured also on basalts recovered on Leg 26, at Sites 253 and 254 on the southern end of Ninetyeast Ridge (Ade-Hall, 1974). The overlying sediment at these sites suggested that this portion of Ninetyeast Ridge was close to sea level during its formation (Davies et al., 1973), although in contrast to the Leg 38 samples, the 
TABLE 2

Stability of Each Specimen Against AF Demagnetization

\begin{tabular}{|c|c|c|c|c|c|c|c|}
\hline \multirow{2}{*}{$\begin{array}{c}\text { Sample } \\
\text { (Interval in } \mathrm{cm} \text { ) }\end{array}$} & \multicolumn{2}{|c|}{ NRM } & \multicolumn{2}{|c|}{$\begin{array}{c}\text { After AF } \\
\text { Demagnetization }\end{array}$} & \multirow{2}{*}{$\begin{array}{l}\text { Hd } \\
\text { (oe) }\end{array}$} & \multirow{2}{*}{$\begin{array}{l}\text { MDF } \\
\text { (oe) }\end{array}$} & \multirow{2}{*}{$\begin{array}{c}J_{100 / \mathrm{NRM}} \\
(\%)\end{array}$} \\
\hline & D & I & D & I & & & \\
\hline \multicolumn{8}{|l|}{ Site 336} \\
\hline $\begin{array}{l}41-1,1 \mathrm{~B} \\
41-1,14 \mathrm{~B} \\
42-1,1 \mathrm{~B} \\
42-1,144 \\
42-2,82 \\
43-1,123 \\
44-1,94 \\
44-2,71 \\
44-2,105\end{array}$ & $\begin{array}{r}21^{\circ} \\
266 \\
229 \\
284 \\
133 \\
204 \\
101 \\
108 \\
37\end{array}$ & $\begin{array}{l}-51^{\circ} \\
-51 \\
-46 \\
-53 \\
-20 \\
-35 \\
-84 \\
-32 \\
-49\end{array}$ & $\begin{array}{r}24^{\circ} \\
250 \\
235 \\
286 \\
102 \\
204 \\
125 \\
101 \\
55\end{array}$ & $\begin{array}{l}-54^{\circ} \\
-46 \\
-49 \\
-57 \\
-46 \\
-34 \\
-77 \\
-36 \\
-58\end{array}$ & $\begin{array}{l}100 \\
100 \\
100 \\
100 \\
200 \\
100 \\
100 \\
100 \\
100\end{array}$ & $\begin{array}{r}233 \\
187 \\
195 \\
261 \\
257 \\
209 \\
81 \\
132 \\
135\end{array}$ & $\begin{array}{l}87 \\
79 \\
84 \\
93 \\
76 \\
88 \\
28 \\
62 \\
60\end{array}$ \\
\hline \multicolumn{8}{|l|}{ Site 337} \\
\hline $\begin{array}{l}13-1,80 \\
13-2,37 \\
13-2,140 \\
13-3,38 \\
14-2,91 \\
15-2,137\end{array}$ & $\begin{array}{r}90 \\
70 \\
272 \\
303 \\
132 \\
235\end{array}$ & $\begin{array}{r}12 \\
-79 \\
-27 \\
22 \\
-65 \\
-77\end{array}$ & $\begin{array}{r}84 \\
70 \\
271 \\
302 \\
138 \\
242\end{array}$ & $\begin{array}{r}15 \\
-79 \\
-32 \\
20 \\
-65 \\
-75\end{array}$ & $\begin{array}{l}200 \\
200 \\
150 \\
200 \\
150 \\
150\end{array}$ & $\begin{array}{l}405 \\
368 \\
226 \\
205 \\
239 \\
235\end{array}$ & $\begin{array}{l}94 \\
98 \\
85 \\
93 \\
93 \\
91\end{array}$ \\
\hline \multicolumn{8}{|l|}{ Site 338} \\
\hline $\begin{array}{l}43-2,115 \\
43-2,41 \\
43-4,54 \\
44-3,40 \\
44-3,91 \\
45-1,127 \\
45-2,56\end{array}$ & $\begin{array}{r}322 \\
27 \\
98 \\
44 \\
33 \\
336 \\
354\end{array}$ & $\begin{array}{l}71 \\
70 \\
31 \\
52 \\
70 \\
63 \\
68\end{array}$ & $\begin{array}{r}300 \\
30 \\
156 \\
47 \\
30 \\
312 \\
358\end{array}$ & $\begin{array}{l}71 \\
72 \\
79 \\
57 \\
68 \\
73 \\
73\end{array}$ & $\begin{array}{l}100 \\
100 \\
100 \\
100 \\
100 \\
100 \\
100\end{array}$ & $\begin{array}{r}234 \\
181 \\
59 \\
69 \\
127 \\
74 \\
86\end{array}$ & $\begin{array}{l}89 \\
82 \\
43 \\
22 \\
61 \\
32 \\
41\end{array}$ \\
\hline \multicolumn{8}{|l|}{ Site 342} \\
\hline $\begin{array}{l}7-2,137 \\
7-5,126 \\
8-2,65\end{array}$ & $\begin{array}{r}341 \\
172 \\
42\end{array}$ & $\begin{array}{r}-7 \\
-86 \\
-79\end{array}$ & $\begin{array}{r}354 \\
175 \\
90\end{array}$ & $\begin{array}{l}-75 \\
-86 \\
-82\end{array}$ & $\begin{array}{l}100 \\
100 \\
100\end{array}$ & $\begin{array}{r}94 \\
265 \\
175\end{array}$ & $\begin{array}{r}46 \\
92 \\
126\end{array}$ \\
\hline \multicolumn{8}{|l|}{ Site 343} \\
\hline $13-2,20$ & 133 & 75 & 134 & 78 & 100 & 75 & 35 \\
\hline \multicolumn{8}{|l|}{ Site 344} \\
\hline $\begin{array}{l}34-2,27 \\
35-4,87 \\
36-2,75 \\
37-1,85 \\
37-2,135\end{array}$ & $\begin{array}{r}194 \\
42 \\
197 \\
170 \\
357\end{array}$ & $\begin{array}{r}-69 \\
-34 \\
-3 \\
-27 \\
-27\end{array}$ & $\begin{array}{r}211 \\
37 \\
191 \\
267 \\
358\end{array}$ & $\begin{array}{l}-77 \\
-29 \\
-72 \\
-71 \\
-70\end{array}$ & $\begin{array}{l}100 \\
300 \\
200 \\
100 \\
100\end{array}$ & $\begin{array}{r}363 \\
149 \\
43 \\
189 \\
396\end{array}$ & $\begin{array}{r}94 \\
107 \\
34 \\
68 \\
113\end{array}$ \\
\hline \multicolumn{8}{|l|}{ Site 345} \\
\hline $\begin{array}{l}33-2,56 \\
35-1,145\end{array}$ & $\begin{array}{r}27 \\
254\end{array}$ & $\begin{array}{l}79 \\
70\end{array}$ & $\begin{array}{r}25 \\
262\end{array}$ & $\begin{array}{l}81 \\
74\end{array}$ & $\begin{array}{l}150 \\
100\end{array}$ & $\begin{array}{l}91 \\
61\end{array}$ & $\begin{array}{l}41 \\
16\end{array}$ \\
\hline \multicolumn{8}{|l|}{ Site 348} \\
\hline $\begin{array}{l}32-4,93 \\
34-2,107\end{array}$ & $\begin{array}{r}3 \\
326\end{array}$ & $\begin{array}{l}43 \\
38\end{array}$ & $\begin{array}{l}279 \\
259\end{array}$ & $\begin{array}{l}-76 \\
-70\end{array}$ & $\begin{array}{l}400 \\
200\end{array}$ & $\begin{array}{l}32 \\
31\end{array}$ & $\begin{array}{l}7 \\
4\end{array}$ \\
\hline \multicolumn{8}{|l|}{ Site 350} \\
\hline $\begin{array}{l}14-2,108 \\
14-3,84 \\
16-2,30 \\
16-2,115 \\
16-3,73\end{array}$ & $\begin{array}{r}145 \\
166 \\
270 \\
174 \\
38\end{array}$ & $\begin{array}{r}-54 \\
-64 \\
8 \\
47 \\
76\end{array}$ & $\begin{array}{r}94 \\
161 \\
224 \\
227 \\
258\end{array}$ & $\begin{array}{l}-67 \\
-65 \\
-87 \\
-49 \\
-66\end{array}$ & $\begin{array}{l}100 \\
100 \\
100 \\
200 \\
100\end{array}$ & $\begin{array}{r}211 \\
293 \\
96 \\
28 \\
437\end{array}$ & $\begin{array}{r}108 \\
99 \\
289 \\
6 \\
79\end{array}$ \\
\hline
\end{tabular}

Note: Declination (D) and inclination (I) of the natural remanent magnetism (NRM) compared to that of the stable component obtained after partial demagnetization in a peak alternating field (AF) intensity (Hd). The declination direction is for an arbitrary fiducial in each specimen. MDF is the median destructive field, and $\mathrm{J}_{100 / N R M}$ is the fraction of the NRM remaining after AF treatment in 100 oe. 
TABLE 3

Magnetization Polarity and Mean Remanent Inclinations of Igneous Rocks at Leg 38 Sites

\begin{tabular}{|c|c|c|c|}
\hline Site & $\begin{array}{c}\text { Number } \\
\text { of } \\
\text { Samples }\end{array}$ & Polarity & $\begin{array}{c}\text { Mean } \\
\text { Inclination } \\
( \pm \text { S. D. })\end{array}$ \\
\hline 336 & 9 & Reversed & $-50.8^{\circ} \pm 12.9^{\circ}$ \\
\hline 33 & 6 & $(\operatorname{Mix}$ & - \\
\hline 338 & 7 & Norn & $70.4^{\circ} \pm 6.8^{\circ}$ \\
\hline 342 & 3 & Reversed & $-81.0^{\circ} \pm 5.6^{\circ}$ \\
\hline 343 & 1 & Norm & $78.0^{\circ}$ \\
\hline 344 & 5 & Reversed & $-63.8^{\circ} \pm 19.6^{\circ}$ \\
\hline 345 & 2 & Normal & $77.5^{\circ}$ \\
\hline 348 & 2 & Reversed & $-73.0^{\circ}$ \\
\hline 350 & 5 & Reversed & $-66.8^{\circ} \pm 13.5^{\circ}$ \\
\hline
\end{tabular}

TABLE 4

Curie Temperatures of Igneous Rock Samples

$\begin{array}{cc}\text { Sample } & \text { Curie Point During } \\ \text { (Interval in } \mathrm{cm}) & \text { Heating Cycle }\left({ }^{\circ} \mathrm{C}\right)\end{array}$

\begin{tabular}{ll}
\hline Site 336 & \\
$41-1,1 B$ & 560 \\
$42-1,144$ & 565 \\
$44-2,71$ & 545
\end{tabular}

Site 337

$\begin{array}{ll}13-2,140 & 285 \\ 14-2,91 & 315 \\ 15-2,137 & 305\end{array}$

Site 338

$\begin{array}{ll}43-2,115 & 405,570 \\ 43-4,54 & 315,565 \\ 45-2,56 & 310,485\end{array}$

Site 342

$7-2,137$

$7-5,126$

230,480

$8-2,65$

245,520

Site 343

$13-2,20$ 310

Site 344

$34-2,27$

$35-4,87$

$37-2,135$

Site 345

$33-2,56$

$35-1,145$

315

Site 348

$32-4,93$

$34-2,107$

340

315

Site 350

$16-2,30$ 190

recovered basalts were described as oceanic tholeiites (Kempe, 1974).

It thus appears that the presence of high Curie temperature magnetic minerals in oceanic basement
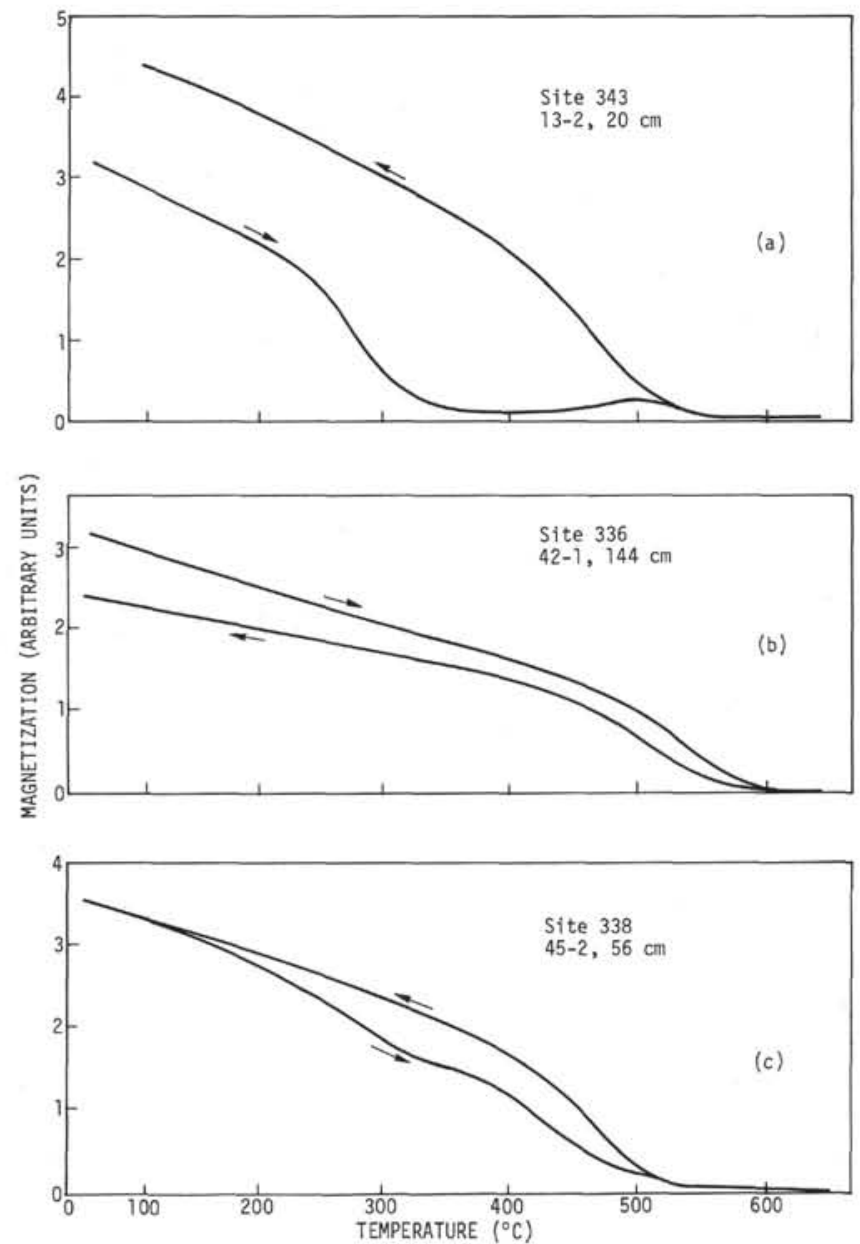

Figure 3. Thermomagnetic curves representative of the basalts from Leg 38. Heating and cooling were performed in air in a field of 3000 oe.

volcanics may be associated with shallow water or subaerial emplacements of the basalt, although their absence would not necessarily preclude such an origin. The mechanism by which this can occur may be related to a greater availability of oxygen to enhance the high temperature oxidation of the original titanomagnetite in the cooling basalt. Alternatively, high regional hydrothermal alteration can also produce high Curie points (Ade-Hall et al., 1971). However, petrologic descriptions suggest that the rocks at the high Curie temperature sites range from little altered (Sites 336 and 342 ) to highly altered (Site 338), not substantially different from the alteration states at the other Leg 38 sites with low Curie temperatures. In addition, equal or greater thicknesses of sediment overlie basaltic basement at most of the other Leg 38 sites with low Curie temperature magnetic mineralogies (Talwani et al., 1975). Unless some appreciable thickness of sediment or basalt has been eroded at the high Curie point sites, it seems unlikely that hydrothermal alteration (e.g., burial metamorphism) is the mechanism responsible for the high Curie temperatures, at least in these cases.

\section{ACKNOWLEDGMENTS}

This research was supported by Grant DES 74-17965 of the National Science Foundation. 


\section{REFERENCES}

Ade-Hall, J.M., 1974. Strong field magnetic properties of basalts from DSDP Leg 26. In Davies, T.A., Luyendyk, B.P., et al., Initial Reports of the Deep Sea Drilling Project, Volume 26: Washington (U.S. Government Printing Office), p. 529-532.

Ade-Hall, J.M., Palmer, H.C., and Hubbard, T.P., 1971. The magnetic and opaque petrological response of basalts to regional hydrothermal alteration: Geophys. J., v. 24, p. 137-174.

Ade-Hall, J.M., Wilson, R.L., and Smith, P.J., 1964. The petrology, Curie points and natural magnetizations of basic lavas: Geophys. J., v. 9, p. 323-336.

Kempe, D.R.C., 1974. The petrology of the basalts; Leg 26. In Davies, T.A., Luyendyk, B.P., et al., Initial Reports of the Deep Sea Drilling Project, Volume 26: Washington (U.S. Government Printing Office), p. 465-504.

Lowrie, W., 1973. Viscous remanent magnetization in oceanic basalts: Nature, v 243, p. 27-30.

1974. Oceanic basalt magnetic properties and the Vine and Matthews hypothesis: J. Geophys., v. 40, p. 513-536.

Lowrie, W., Lovlie, R., and Opdyke, N.D., 1973. Magnetic properties of Deep Sea Drilling Project basalts from the
North Pacific Ocean: J. Geophys. Res., v. 78, p. 76477660 .

Ozima, M. and Ozima, M., 1971. Characteristic thermomagnetic curve in submarine basalts: J. Geophys. Res., v. 76, p. 2051-2056.

Peirce, J.W., Denham, C.R., and Luyendyk, B.P., 1974. Paleomagnetic results of basalt samples from DSDP Leg 26, Southern Indian Oceán. In Davies, T.A., Luyendyk, B.P., et al, Initial Reports of the Deep Sea Drilling Project, Volume 26: Washington (U.S. Government Printing Office), p. 517-527.

Davies, T.A., Luyendyk, B.P., Rodolfo, K.S., Kempe, D.R.C., McKelvey, B.C., Leidy, R.D., Horvath, G.J., Hyndman, R.D., Theirstein, H.R., Boltovskoy, E., and Doyle, P., 1973. Deep Sea Drilling Project Leg 26: Geotimes, v. 18, p. 16-19.

Talwani, M. and Eldholm, O., 1972. Continental margin off Norway: A geophysical study: Geol. Soc. Am. Bull., v. 83, p. 3575-3606.

Talwani, M., Udintsev, G., Bj申rklund, K., Caston, V.N.D., Faas, R.W., Kharin, G.N., Morris, D.A., Muller, C., Nilsen, T.H., van Hinte, J.E., Warnke, D.A., and White, S.M., 1975. Deep Sea Drilling Project Leg 38: Geotimes, v. 20 , p. $24-26$.

Vine, F.J. and Matthews, D.H., 1963. Magnetic anomalies over oceanic ridges: Nature, v. 199, p. 947-949. 